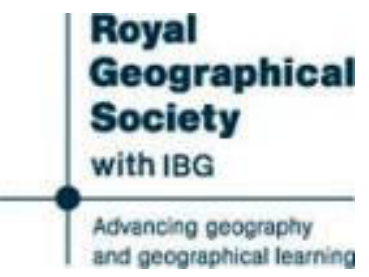

Notes on the Seasons in Equatorial Africa

Author(s): F. W. H. Migeod

Source: The Geographical Journal, Vol. 59, No. 1 (Jan., 1922), pp. 52-55

Published by: The Royal Geographical Society (with the Institute of British Geographers)

Stable URL: http://www.jstor.org/stable/1781859

Accessed: 23-03-2015 12:41 UTC

Your use of the JSTOR archive indicates your acceptance of the Terms \& Conditions of Use, available at http://www.jstor.org/page/info/about/policies/terms.jsp

JSTOR is a not-for-profit service that helps scholars, researchers, and students discover, use, and build upon a wide range of content in a trusted digital archive. We use information technology and tools to increase productivity and facilitate new forms of scholarship. For more information about JSTOR, please contact support@jstor.org.

The Royal Geographical Society (with the Institute of British Geographers) is collaborating with JSTOR to digitize, preserve and extend access to The Geographical Journal. 


\section{NOTES ON THE SEASONS IN EQUATORIAL AFRICA}

\section{F. W. H. Migeod}

T LEFT England towards the end of I9I9 on an expedition across 1 Africa, my intention being to keep as near to the equator as I reasonably could without very great difficulty.

Whilst still on my way down the coast to Libreville in Gabon, where my overland journey was to begin, I had expected to find the dry season by the beginning of January, as I was still in the northern hemisphere. Instead of that there was heavy rain, which continued all through January; and rain in that month is a feature of the southern hemisphere. It seemed as if here on the western side of the continent there was a tendency for the southern seasons to intrude on the territory of the northern, and push the latter back, actually displacing them. For a certain number of degrees of latitude, therefore, the seasons were the opposite of what they should be, and it was only at the northern limit of this invasion that the normality prevailed which should have been found on the equator itself.

I studied this feature at every halting-place during the whole of my journey, which lasted eleven months, until I reached the Indian Ocean. Where there were no available statistics I took the opinions of local residents. The bulk of the information seems to show that for the greater part of the length of the equator the superior strength of the southern seasons is clearly noticeable. The area covered was wide enough to eliminate local disturbing influences. Even if the latter did produce some modification, it did not seem to be enough to affect the general principle.

I obtained good information in regard to Libreville, my starting place. This town, which is in lat. $0^{\circ} 25^{\prime} \mathrm{N}$., should bave the January dry season fairly well marked. An average, however, of three years gives the period December to March as very wet; and it certainly rained very hard whilst I was there in January. On the other hand, June and July are practically dry. This, I think, can only indicate that Libreville is under the southern influence. The same applies to Principe Island in lat. $\mathrm{I}^{\circ} 5^{\prime} \mathrm{N}$. The rain falls there between September and March, tornadoes only being expected during the rest of the year. At the western end of the equatorial zone, therefore, the limit of the invading southern seasons may be placed well to the northward of the geographical equator. To place it near two degrees north might, in the absence of further information from the neighbourhood, not be to place it too far.

Leaving Libreville, the first place I stopped at was Kango, at the head of the Gabon estuary, about 60 miles direct from the coast and roughly on the same latitude as Libreville. Here I was informed that from May to October there are all the features of the southern dry 
season. It is dry, cloudy, and windy. In January and part of February there is also a small dry season. Its tendency should be, if not exactly equal, a little stronger than the mid-year dry season, for Kango is not south of the equator. On the contrary, it is small both in duration and force compared with the southern influence. Further inland, at Bue, which lies on the Cgowe river, and is almost exactly on the equator, June to October is called the Big dry season, and January and February the Small dry season. There is thus no idea locally of an even balance between the two. To the north-east of Bue is Makoku, in lat. $\circ^{\circ} 35^{\prime} \mathrm{N}$. Here also the Small dry season is at the beginning of the year, and the Big dry season in the middle of the year. At Etumbi, on the Likuala river, practically on the equator as far as has been ascertained, and in about long. $15^{\circ} \mathrm{E}$., the July dry season is bigger than the January one.

A short distance east and on the same river is Makwa. This place is precisely on the equator. Here I saw official records covering just over a year. Rain fell in every month of the year, but was rather heavier in the months at the beginning of the year than the mid-year months, which clearly shows the overbalance to the north of the southern seasonal influence. As far as French territory is concerned, therefore, the line of the preponderance of the southern seasons seems undoubtedly well to the north of the geographical equator all the way from west to east. At what degree of latitude, however, to place it in the east there is not sufficient information available.

I should have liked to have obtained statistics at Coquilhatville in the Belgian Congo, which is exactly on the equator. General opinion was that the seasons there are irregular. There had not long previously been a drought of seven months. Anyhow, in early June there was a strong south-west wind blowing for half the day, and strongest in the forenoon; so that the southern seasonal influence was certainly not non-existent. There were also occasional tornadoes.

Alberta station, a palm-oil plantation and factory of Messrs. Lever Bros., is on the northerly bend of the Congo, in lat. $2^{\circ} \mathrm{ro} \mathrm{o}^{\prime} \mathrm{N}$., and about long. $22^{\circ} 20^{\prime} \mathrm{E}$. There is rain here nearly all the year round, but the northern seasons are shown in the statistics as holding their own, which is as might be expected in so high a latitude. The dry season is from the middle of December to the middle of February, though it is not entirely without rain. The effect of the southern dry season was scarcely noticeable for the one year for which I saw figures. Indeed, rain fell very heavily. It is to be expected that in so high a latitude as is Alberta the northern seasons should predominate, though not to the extent the statistics indicate. I had hoped to find good statistics at Stanleyville, but was informed there were none.

Bafwaboli, in lat. $0^{\circ} 35^{\prime} \mathrm{N}$., long. $26^{\circ} 30^{\prime} \mathrm{E}$., is in the midst of the dense forest and on the Chopo river. It rains here in every month of the year; but, as two years' figures show, a trifle less in January and February 
than in the mid-year months. Bafwaboli, therefore, gives the same negative results as Alberta. At Avakubi, lat. $1^{\circ} 20^{\prime} \mathrm{N}$., long. $27^{\circ} 30^{\prime} \mathrm{E}$., I obtained good statistics. It is on the Ituri river and in dense forest, and rain falls in every month of the year. The January dry season is here slightly stronger than the mid-year dry season, taking an average of years, though in I $\mathbf{9} \mathbf{I} 7$ it was slightly the reverse. At Penge, not a degree to the eastward of Avakubi, I was informed by an old resident, a trader, that he considered the dry season at the beginning of the year the principal one. When eventually I came out of the forest and reached Irumu, still in about the same latitude, $\mathrm{I}^{\circ} 30^{\prime} \mathrm{N}$., I learnt that the January dry season was the more important, but whether its influence was about normal or varied from normality I could not ascertain.

Coming now into Uganda: there seemed to be some uncertainty about the seasons. Both Mount Ruwenzori and Lake Victoria exert considerable local influence, and between the two is a dry belt. I was told at Kampala, which is just north of the equator, that the southern dry season seems to be rather the more influential as a dry season; but I was unable to confirm this precisely from the meteorological reports which I saw, as the figures seemed to indicate nothing very pronounced either way. Anyhow, there seems to be at Kampala a very strong wind in June; and high wind is the normal accompaniment of the southern dry season. At Kisumu, at the north-eastern corner of Lake Victoria, in lat. $0^{\circ} 7^{\prime} \mathrm{S}$., there is rain all the year round, and it is difficult to form any clear deduction without having the figures for a long period of years. At the observation station of Kabete, near Nairobi, in $I^{\circ} I^{\prime} \mathrm{S}$., the mid-year dry season seems stronger. This, however, is no more than it should be from the position. The same feature is shown by one year's figures at Fort Hall, which lies in a north-easterly direction from Nairobi, and in lat. $0^{\circ} 43^{\prime} \mathrm{S}$. There almost seems to be a tendency at these two places for the northern seasonal influence completely to hold back the southern, but whether the balance is at the equator or even just below it, there is not sufficient to decide. Nevertheless the total reversal of the conditions that prevail on the west coast is seen at Mombasa. Although this place is as far south as $4^{\circ} 4^{\prime} \mathrm{S}$., it has the cool northern dry season, and generally it seems to have a climate of its own that does not harmonize at all with general conditions.

The southern seasonal overbalance, therefore, which, west of the Congo river, is so far to the north, is less conspicuously so when that river is reached and passed after it has cut the equator. After leaving Kisumu the overbalance is completely lost, and when the east coast is reached there is a total reversal, and the northern influence powerfully pushes back the southern seasons.

As the seasons follow the vertical sun in the tropics, some reason must be sought for these variations, which from their magnitude cannot well be classed as purely due to local causes. The eight days' longer 
sojourn of the sun in the northern hemisphere may be one. Another may be the preponderating mass of water compared with land in the southern hemisphere. Should it be either of these causes, or both acting together, then the disturbing tendency as seen in East Africa may be due to the Sahara desert. This desert from its extreme western limit near Cape Verde trends eastward with a slight southerly dip until it crosses the Nile. Thence the dip is nearly entirely south-easterly, until eventually the southern edge of the sand comes to the south of the equator. It must undoubtedly be the desert, with the special winds it sets up, which accounts for the exceptional climate of Mombasa.

In examining this subject it must of course be borne in mind that it is not the actual quantity of rain that falls which governs the situation, but the relative quantity. A rainy season may be well defined though the rainfall be small. The same holds good in the reverse way with the dry seasons. I know of places in close proximity to one another with very different quantities of rainfall. In one I recall in another part of Africa the dry seasons and rainy seasons were very clearly distinguished. Yet 30 miles away in a straight line to the northward, and with only a few hundred feet rise, there were only rainy and wet seasons, the enormous precipitation almost swamping the dry tendency. Nevertheless these two places have the same relative proportion as regards the opposite seasons.

\section{GEOGRAPHY AND HISTORICAL GEOGRAPHY}

\section{The Geography of the Ozark Highland of Missouri.- Dr. Carl Sauer. University of Chicago Press. 1920. Pp. xviii. +246 . Price 3 dollars.}

$\mathrm{D}^{\mathrm{R}}$ R. CARL SAUER, of the University of Michigan, has recently written a very interesting monograph which has a twofold purpose: "To furnish an adequate explanation of the conditions of life in a given area, and to contribute proved statements which will aid in working out fundamental principles." The purpose is admirably accomplished and the study is a notable contribution to geographical science, but the inclusion of an account of the settlement and development of the region raises the question of the scope and aims of Geography and Historical Geography respectively, and at the same time supplies material to illustrate the relations between these two branches of knowledge.

Geographers seem to be approaching a general agreement about the content of their subject, but it is more difficult to obtain a clear idea of what Historical Geography should include and at what it should aim. Dr. Sauer seems to the present writer to be quite clear about the relations between Geology and Geography, but to include as Geography much that is appropriate only to Historical Geography.

In the selection and explanation of the facts of the physical geography of the Ozark Highlands, Dr. Sauer adopts criteria which may be quoted. "Only those things which are pertinent to an understanding of the conditions under which the people live are introduced. Rock formations are of significance in this connection in so far as they have determined topographic features, soils 